\title{
Questões jurídicas relativas à sociedade da informação
}

Entrevista concedida pela Deputada federal Zulaiê Cobra Ribeiro

Deputada pelo PSDB de São Paulo, Zulaiê Cobra Ribeiro é advogada formada pela PUC/SP. Foi assessora jurídica e sócia fundadora do SOS Mulher e Pronto-Socorro da Mulher Paulista. Atuou, em 1985, como assessora parlamentar da II Reunião Preparatória da IV Conferência Mundial sobre a Mulher: Ação para a Igualdade, Desenvolvimento e Paz em Nova York. Atualmente é relatora da Reforma do Poder Judiciário
Ciência da Informação - Existem leis disciplinando a Sociedade da Informação?

Zulaiê Cobra - A questão da Sociedade da Informação lembra um pouco o caso Mercosul. O Mercosul está criando grandes problemas na justiça porque a legislação não acompanha o processo na mesma velocidade. Você não pode deter um caminhão que está vindo do Uruguai e que vai para o estado do Amazonas. Se este caminhão é detido no Brasil, na divisa com o Paraguai, estamos diante da exigência de uma legislação que atinge quatro países.

Ciência da Informação - Quais são as dificuldades legais para punir crimes no contexto da Sociedade da Informação?

Zulaiê Cobra - No caso da Internet, você está diante de uma dificuldade até na maneira de a lei ser aplicada, pois a Internet não tem a ver só com a lei brasileira, atinge as leis de outros países, assim como a questão da comunicação visual. Então, quando você acessa a Internet, você pode estar entrando em lugares diferentes. Já houve caso, aqui no Brasil, de hackers que entraram nos sites do Banco Central e da Receita Federal. Isso é um perigo. A legislação está surgindo em função da natureza dos crimes que ocorrem na Internet.

Ciência da Informação - Existe algum esforço para que o judiciário se modernize e possa fazer frente às necessidades da Sociedade da Informação?

Zulaiê Cobra - Primeiro, o judiciário tem de se modernizar em termos de informática. A informação e a informática não existem no contexto do Poder Judiciário. Nós estamos tentando fazer com que o ministro da Justiça e a Polícia Federal criem um banco de dados com informações sobre todos os criminosos do Brasil. Hoje, a polícia do Paraná não pode investigar e atuar no estado de São Paulo, porque tem aquela coisa do território. Por outro lado, a polícia de São Paulo não pode entrar em Roraima, nem no Rio Grande do Sul. Então, você tem uma legislação que não permite a união de todas as ações policiais em torno de uma legislação nacional. Em outras palavras, você não tem o emprego da ação conjunta por meio de informações sistematizadas. 
Ciência da Informação - Como o Supremo Tribunal Federal situa-se nestes novos tempos?

Zulaiê Cobra - O STF só agora está despertando para a necessidade da possibilidade de um advogado, ou mesmo o cidadão comum, entrar e pesquisar os julgamentos, isso é ótimo, é a transparência. A sociedade precisa saber como o juiz está julgando, quais são as decisões que estão sendo tomadas. Hoje, no STF você pode pesquisar determinados tipos de temas, mas isso não serve para tudo. No Tribunal de Justiça de São Paulo, se você pesquisar, via Internet, vai encontrar apenas algumas informações, mas não encontrará todas as informações necessárias. Nós temos um Judiciário ainda despreparado para a era da informação. Eu fui vereadora no município de São Paulo. A Câmara municipal de São Paulo, que é a maior Câmara do Brasil, não é informatizada, porque não interessa às pessoas que estão compondo a mesa que tudo seja feito às claras. Em sentido contrário, noExecutivo de São Paulo, o governador Mário Covas colocou todas as secretarias em rede. Se você quer saber quanto gastou a Secretaria de Educação em 1999 com merenda escolar, está lá. Todas as secretarias do estado de São Paulo estão informatizadas. Isto é o que nós queremos para a Justiça, e vamos ter dificuldades porque a Justiça caminha com passos de tartaruga.

Ciência da Informação - Existe uma razão para que a Justiça brasileira não se modernize?

Zulaiê Cobra - A justiça alega que não tem condições materiais para que todas as varas de todos os município brasileiros tenham um computador. E não é só ter o computador, mas tê-los interligados, entre os tribunais de justiça dos estados e as varas municipais. Tudo isso interligado aos Tribunais Superiores em todos os níveis e instâncias.

Ciência da Informação - Qual é o papel da informação no contexto do novo Código Penal?

Zulaiê Cobra - A informação é necessária e vital para que todos os brasileiros tenham contato com temas do seu interesse. Mas, por outro lado, outras formas de criminalidade e delinqüência estão surgindo em função deste mesmo contexto. Estão surgindo outros crimes que não conhecíamos até então. Nós acabamos de fazer um código penal, e esse código não define crimes decorrentes do uso da Internet. Portanto, daqui a cinco ou seis anos vamos ter de mudar de novo a legislação penal, porque os crimes estão surgindo agora. A informação é necessária para dar transparência, fornece o conhecimento. Certamente estão por surgir outros crimes que nós não podemos nem imaginar nos dias de hoje.
Ciência da Informação - Determinados crimes como os casos de pedofilia na Internet poderiam ser julgados com a legislação vigente?

Zulaiê Cobra - Eu acho que nós vamos ter de criar leis para os crimes que estão acontecendo. Mas a grande dificuldade é a interpretação do crime. $O$ crime de pedofilia na Internet é uma coisa nova, portanto não pode ser julgado com leis antigas.

Ciência da Informação - A justiça brasileira acaba se tornando ineficaz em razão da demora e da lentidão. A senhora não acha que as novas tecnologias de informação podem proporcionar transparência e agilizar esta morosidade?

Zulaiê Cobra - A transparência e a informação são fundamentais. Se você tivesse a possibilidade de saber o que os juízes estão julgando, conseqüentemente você poderia exercer maior pressão, e, desta forma, teríamos um Judiciário mais ágil. Hoje, você tem um acúmulo de ações e, por outro lado, você tem a morosidade. A partir do momento em que o juiz sabe que qualquer pessoa daquela cidade, daquela comarca, tem acesso via Internet aos seus julgamentos, que o juiz está com 250 processos parados em suas mãos, então este juiz será pressionado pela sociedade a trabalhar mais. Como ser ágil, se hoje muitas salas de audiência não têm sequer computador?

Ciência da Informação - A senhora poderia citar um exemplo sobre como a Sociedade da Informação poderá atender ao Poder Judiciário?

Zulaiê Cobra - Nós estamos implantando normas em alguns presídios brasileiros. No caso de São Paulo, o réu não precisa ir à sala de audiência. Existe um telão, e o réu responde às perguntas do juiz, com o advogado ao lado. O réu não precisa se deslocar. Com isso, você faz economia de transporte e guarda. Você está economizando a saída de um preso de alta periculosidade de uma cadeia, evitando o seu deslocamento por vários quilômetros para ser interrogado. O juiz vem até o réu, e o réu vai até o juiz, por meio da informática e dos recursos de comunicação. Se o Judiciário for todo informatizado, e este é o nosso anseio, nós vamos ter um Judiciário mais ágil. Significa agilidade e transparência. Como as sentenças estarão disponíveis, a comunicação do Judiciário com o povo ficará mais rápida. 


\section{ENTREVISTA}

Ciência da Informação - Com relação aos crimes decorrentes de negócios comerciais na rede, como a senhora avalia esta questão?

Zulaiê Cobra - O que eu tenho observado é que existe um critério por parte de quem comercializa na Internet, é o critério da decência. Quem comercializa na rede está sabendo que, se não der certo, todos estarão falidos, mas, se der certo esta forma de comércio, via Internet, todos estarão milionários. Então, o que eu vejo é um comércio impecável. O produto chega à sua casa nas melhores condições, mais do que você possa imaginar. A propaganda da venda via Internet é assim: nós nunca falhamos. Agora eu concordo plenamente que nós precisamos ter uma legislação para que o produto chegue à sua casa.
Ciência da Informação - Hoje a realidade da Sociedade da Informação ainda é para poucos. Como a senhora vê a questão do acesso para todos?

Zulaiê Cobra - Antigamente ninguém tinha televisão. Há 35 anos, eram poucas as pessoas que tinham televisão, as casas que tinham contavam-se nos dedos. Hoje, existe alguma casa que não tenha televisão? Não é apenas um aparelho, hoje muitas casas têm um, dois, três e até quatro aparelhos. Então a tendência é você estender todas estas tecnologias de informática e comunicação para todo mundo. $\mathrm{O}$ acesso torna-se uma coisa banal como é nos Estados Unidos. Você tem exemplos clássicos: em alguns países a tecnologia é tão avançada que você, quando vai alugar uma casa, já aluga com televisão, telefone, geladeira, tem tudo, isso é um avanço. A linha telefônica não caiu de preço? Antigamente poucas casas tinham telefone, uma linha telefônica em São Paulo chegou a custar cerca de R \$ 4 mil. O telefone é o maior exemplo de que, se o governo tiver uma política pública orientada para a democratização das tecnologias de informação, este benefício certamente chegará a todos os brasileiros. Com toda a certeza, nós viveremos em um país melhor.

Entrevista concedida no dia 18 de outubro de 2000 a Almerita Ferreira dos Santos Sabóia e Pedro Anísio Figueiredo (Ibict) 